\title{
4 \\ Solidarities Across: Borders, Belongings, Movements
}

One way to illuminate the ways in which spaces of resistance are enabled, transformed, or restrained is by focusing on solidarity practices. In Chapter 2, we argued for the centrality of solidarity practices in the making and expansion of spaces of resistance. We also discussed, from the perspective of transnational feminism, that the differential positioning of feminist and LGBTI+ activists in terms of political agendas and geographical location highlights the significance of activist efforts to recognize differences based on class, race, ethnicity, and religion when building transnational solidarities (Baksh and Harcourt 2015; Bassel and Emejulu 2017; Gender \& Development 2013; Irvine et al. 2019; Martinsson and Mulinari 2018; Salem 2017; Scholz 2014; Social Politics 2018; Wiedlack et al. 2019). In this chapter, we take a closer look into practices of solidarity across borders, belongings, and movements. Building on the notion of solidarity across difference developed by Jodi Dean (1996) and Chandra Talpade Mohanty (2003), we offer ethnographic accounts of activist work oriented to recognizing and challenging inequalities and relations of oppression based on race, 
ethnicity, religion, and class, alongside gender and sexuality. As we draw on an emerging body of literature that highlight everyday practices of solidarity (Ahmed 2014; Butler 2018; Chowdhury and Philipose 2016; Connections 2020; Hemmings 2012; Salem 2017; Pedwell 2012; Wiedlack et al. 2019), our aim is to expose the embodied and affective processes involved in community- and coalition-building transnationally, that is on local, national, regional, and global levels simultaneously. In doing so, we wish to foster conceptualizations of solidarity beyond, or against, nation-bound, rights-oriented frameworks, as this would advance scholarly imaginations of solidarity across difference.

The chapter rests on a definition of solidarity as practices of community- and coalition-building that are embedded in imagined and concrete relationships and take place on multiple scales, in multiple life fields, and between as well as within borders, belongings, and movements. Practices of solidarity include co-ordinated struggles for sharing resources, engaging in symbolic actions, and organizing mutually beneficial programs, campaigns, and advocacy coalitions (Keck and Sikkink 1998; Weldon 2018) as well as small-scale, mundane acts of affinity and friendship (Ahmed 2014; Chowdhury and Philipose 2016; Hemmings 2012; Wiedlack et al. 2019). Whether in the form of informal, smallscale action or more co-ordinated, institutionalized organizing, we consider solidarity practices as political work. This is to clarify a blurred understanding of solidarity as scholars use the concept to refer to "external identity, shared experience, shared consciousness, and political resistance separately and simultaneously" (Scholz 2008, 3). We certainly believe that studying coalition- and community-building efforts based on shared identities, experiences, and consciousness are very important for making sense of feminist and queer struggles. Yet, in this chapter, we focus more on the role of solidarity in the making of collective resilience, resistance, and repair. Rather than having a normative status, practices of solidarity can reproduce or subvert imperialist or nationalist/assimilationist projects and inequalities on different levels (Berger and Scalmer 2018; de Jong 2017; Maiguashca 2016; Pedwell 2012). Regardless of activists' intentions, community- and coalition-building might be hampered by cultural and political diversity, class inequalities 
and economic barriers, and physical distance between activists (Dufour et al. 2010, 9). Greater availability of digital technologies and affordable means of transportation, together with the processes of NGOization we discussed in Chapter 3, facilitate the proliferation of transnational solidarities in many parts of the world. However, the continuationif not deepening - of existing global and local asymmetries of power, organized violence and war, and shifts in gender and sexual politics that jeopardize women's and LGBTI+ lives make solidarities difficult to maintain and often susceptible to contention and conflict. Our interest thus lies in tracing the processes of inclusion and exclusion produced by solidarity practices in order to draw attention to the tensions, challenges, and dilemmas inscribed in transnational solidarities, alongside their emancipatory potential.

What is the role of affinity, friendship, and care, as well as of conflict and dissonance, in creating possibilities of and hindrances to solidarities across borders, belongings, and movements? How do shifts in broader political, social, and economic environments impact on activist understandings of solidarity across difference? How do globally salient binaries such as North/West vs. South/East, religious vs. secular, and liberal/democratic vs. conservative/authoritarian play out in activists' imaginaries and embodied encounters? What are the conditions and effects of their maintenance and/or destabilization? What is the role of history and temporality in contemporary politics and practices of solidarity? What kind of affects are involved in face-to-face and faraway solidarity projects? How do feelings of affection, connection, desire, and pleasure, together with those of anger, pain, frustration, and disappointment, shape the relations among and between different groups of activists? These are the questions that are of relevance to our endeavor in this chapter. As we analyze how terms and relations of solidarity are negotiated by feminist and LGBTI+ activists in the respective contexts of the book, we also bring to light the linkages and mutuality—or their lack thereof-within and across feminist and queer struggles.

In the following sections, we engage a variety of material from feminist and LGBTI+ activisms, including organizations, events, campaigns, and everyday encounters and ongoing struggles. Working through our material, we elaborate on different aspects of conceptualizing practices 
of solidarity across difference. The first section presents two instances of face-to-face encounters where activists address their differential belongings and relations of gender, sexuality, race, ethnicity, and class through deliberation: the 1st European Lesbian* Conference and the conference Fucking Solidarity: Queering Concepts on/from a Post-Soviet Perspective. Both conferences took place in 2017 in Vienna, Austria. Drawing on activists' accounts of these gatherings as well as our own observations, the section problematizes activist efforts to build solidarity across geographic and contextual divides. It highlights tensions arising from activists' conflicting ideas around solidarity and homogenizing categorizations of geographic and contextual difference, and suggests a more nuanced approach to identity that takes into account complicities and overlapping belongings. In the second section, we turn to anti-colonial struggles in Sápmi ${ }^{1}$ through practices pertaining to ethnic, religious, and sexual belongings. Developing an understanding of solidarity as shared labor, this section puts on center stage the ritual of hymn singing in Kirkenes, Norway, and emphasizes the importance of a long-term commitment to working together in addressing and challenging violent assimilatory ambitions of state actors and institutions and reversing colonial processes. The section takes its starting point in a rainbow mass during a transnational Pride event organized in Kirkenes and shines a light on solidarities across ethnic, religious, and sexual differences. The third section unpacks the implications of transnational solidarity campaigns for feminist and queer struggles in different locales by analyzing activist mobilizations around two events: The Turkey

\footnotetext{
${ }^{1}$ In Sami language, Sami people refer to themselves as Sámit (the Samis) or Sápmelaš (of Sami kin). The English spelling of Sami varies between Sámi and Sami, of which Sami is most frequently used. Further, Sami language can be spelt Saami or Sami. The most common usage is Sami. In the book, we follow the most common practice and use Sami for the people and for the language. The territory of the Sami people is called Sápmi (http://www. samer.se/2137, 16/11-20). There is no census for the Sami people but estimations amount to around 80,000 people. The people is situated across four national borders with approximately 20,000 in Sweden, 50,000 in Norway, 8000 in Finland, and 2000 in Russia (https://sweden. se/society/sami-in-sweden/, 16/11-20). As of today, nine Sami languages exist, a division based on linguistic and geographical differences, connecting features of culture, tradition, and place (Hämäläinen et al. 2018). The most common religious belongings of the Sami people are Christianity (Lutheranism including Laestadianism), Eastern Orthodoxy, and Sami Shamanism. The analysis in this chapter focuses on Sami people living in Norway and on usages of the North Sami language.
} 
Women's Gathering in 2019 and the transnational response to stateinitiated homophobic persecutions of LGBTI+ people in Chechnya in 2017. By linking these events to the International Women's Strike (2017-) and the (I)NGO practices of forging global action for LGBTI+ rights, respectively, we show the ambiguities inscribed in transnational solidarity campaigns that serve as a source of inspiration but do not necessarily lead to desirable or intended outcomes. We conclude the chapter with a discussion on the implications of our ethnographic examples for conceptualizing transnational solidarities.

\section{De/stabilizing Divides Through Transnational Solidarities}

Feminist and queer struggles transform locally and globally through transnational encounters that serve as arenas where shared agendas and identities as well as differential belongings are cherished, challenged, and negotiated. Following the Cold War period where the different approaches to gender equality upheld by the First and Second Worlds became markers of their competition in the international arena (de Haan 2018; Popa 2009; see also Chapter 1), the past three decades saw the consolidation of the global North/West as a locus for feminist and LGBTI+ activism claiming financial and moral leadership over the rest of the world that was "unable to govern itself" in terms of gender equality and sexual rights (Spivak 1996, 2; Grewal 2005; Puar 2007). Global governance institutions such as the UN and the World Bank and INGOs that adopted global governance agendas mediated international gatherings of activists across the North-South and East-West despite their different histories of engaging and dis/identifying with the West (Antrobus 2004; Benería et al. 2015; Devaki 2005; Meyer and Prügl 1999; Winslow 1995). At the same time, transnational feminist scholarship and activism widely contested the discursive construction of the South/East by dominant groups and their institutions in the North/West (Mohanty 1984; Spivak 1996), pointed at "Western leveraged pedagogies" as part of Western/European politics of expansion (Kulpa 2014; Wiedlack et al. 2019), and brought into discussion possibilities as well 
as histories of South-South and South-East solidarities (Fernandes 2013; Ghodsee 2019; Roy 2016). Still, asymmetric power relations between the West and the rest, especially in terms of financial and logistic resources (see Chapter 3), maintain the position of Western states and West/Northbased INGOs as the main funder of many transnational encounters. As the below examples show, these power relations overlap with activists' national and/or regional dis/identifications and differential class positions, as well as professional divisions such as academia vs. activism within and between contexts. Thus, attempts to build solidarity across difference through face-to-face encounters can have the ambiguous result of destabilizing certain binaries and identifications in the activist field while reproducing and reinforcing others.

\section{Dissonances Across the (Imagined) West and Non-West}

An example of such ambiguity happened on the occasion of the 1 st European Lesbian* Conference $\left(\mathrm{EL}^{*} \mathrm{C}\right)$ on October 6-8, 2017 in Vienna, Austria, when a group of $\mathrm{LB}_{+}{ }^{2}$ feminists from Turkey attended this conference. The idea of organizing this gathering emerged during the 2016 ILGA Europe Conference in Cyprus, when the need for the empowerment of lesbians and visibility of their struggles surfaced at a lesbian workshop (EL*C n.d.). In order to garner the funding necessary to host the conference, the international group of activists who came up with the conference idea had to register the $\mathrm{EL}^{*} \mathrm{C}$ as an Austria-based NGO. Call for participation in this conference was widely circulated in feminist and LGBTI+ listservs in Turkey. This was a time when Lezbifem (Lezbiyen Biseksüel Feministler), an Istanbul-based informal initiative of $\mathrm{LB}+$ feminists (2015-2018), was most active and having a significant impact on feminist and queer struggles in Istanbul and beyond (Lezbifem n.d.). A number of activists from Lezbifem applied to give a paper presentation at the conference about Lezbifem's activities.

\footnotetext{
${ }^{2} \mathrm{LB}+$ feminists refer to women and non-binary feminists who identify as lesbian, bisexual, panor polysexual, or queer.
} 
Individual activists from Istanbul and Ankara who attended the EL*C without presenting a paper joined them.

Yonca, who back then was organized in Lezbifem and became one of the paper presenters at the $\mathrm{EL}^{*} \mathrm{C}$, provided us with an account of the experience of participants from Turkey. Besides being a member of Lezbifem, Yonca participated in numerous wildcat actions against multiple systems of oppression, acted as a committee member for the Feminist Night March organization (see Chapter 5), and was affiliated with a webbased feminist news site known for its investment in transnational and intersectional feminism. Talking about the $\mathrm{EL}^{*} \mathrm{C}$, Yonca reflected on her experience as one about the realization of whiteness, class-blindness, and trans-exclusionary attitudes on the side of European activists that disappointed but also gave her and her friends a more realistic understanding of the inner workings of $\mathrm{LB}+$ activism in the West. The first instance of disappointment happened prior to their arrival to Austria, when those of them who wanted to attend the conference without presenting a paper were offered a place to sleep in Vienna for free. This was a big, collectively run squat in the city, and attendees' accommodation there would be organized by feminists in Vienna. Yonca did not know which group of feminists specifically, but her friends were told that the space would not be available for transwomen. This raised questions and sparked a discussion in Yonca's and her fellows' minds about the salience of transphobia in the Viennese feminist movement; had such a gathering been organized in Istanbul, they thought, transwomen at no point would be excluded. Yonca herself was a paper presenter so together with her group of friends from Lezbifem they were provided with hotel accommodation. This became the second instance of disappointment, this time due to a realization of class differences between organizers and participants of the $\mathrm{EL}^{*} \mathrm{C}$. "I didn't participate in the organization process so I don't know who made such decisions," said Yonca, "but I think this is an important sign of whiteness; we stayed in terribly expensive hotels. (...) Everything was really 'upper' [class]. That was not necessary; they could have invited more people [to participate in the conference] instead of spending so much money on luxury accommodation."

A third instance of disappointment occurred at a conference session on Black lesbian experiences. During this session, a Black presenter received 
questions about "how it feels to be Black," and then one about "how it feels to be a darker Black." "We never ask such questions..." Yonca objected, "but she [the presenter] responded very well! She said: 'I don't think about my blackness all the time, I don't feel something special about it but probably you do; perhaps you should ask yourself why you do!'." Having witnessed this incident, Yonca became also critical about the positive reception of their own presentation on Lezbifem. She thought that the audience was overly enthusiastic about Lezbifem's street protests and not so much about its politics of bridging feminist and LGBTI+ activisms. She felt irritated by the celebration of LB+ activists' visibility in Turkey because she felt exoticized and romanticized:

They also investigated our looks. I had short hair, the other friend had her head shaved, etc. We were dark but chilled with our queer looks and they were like, 'wow.' This [our looks] had to do with our [upper] class position but they had no awareness on this. (...) Or, for example, they were surprised by our struggle against transphobia or our investment in queer politics. As if we are located [geographically] outside of these discussions!

Yonca's disappointment with her experience around the 1 st $\mathrm{EL}^{*} \mathrm{C}$, which she said was shared by other participants from Turkey, shows how transnational encounters can expose class and racial processes and different understandings of lesbian inclusivity involved in feminist and queer solidarities. A number of dissonances occurred at this gathering between $\mathrm{LB}+$ feminists from Turkey and whom they perceived as a Western community of lesbian activists. Providing presenters with quality accommodation, perhaps intended as a hospitable gesture on the side of conference organizers, was interpreted as a careless act of solidarity that only underscored class differences between activists from different contexts. A separate session on Black lesbians that could be considered as a space for empowerment reproduced, in the eyes of some participants, racial differences by singling out Black lesbian experiences as irreconcilable with those of White lesbians. Finally, the celebration of Lezbifem's street politics and public visibility as the highlight action of the initiative 
read like a dismissal, on the side of Western lesbians, of the initiative's valuable political work of bridging feminist and queer struggles in Turkey. In their street action, Lezbifem rather addressed $\mathrm{LB}+$ exclusion in feminism and misogyny in LGBTI+ activism. Challenging the oppressive Turkish state was not necessarily high on Lezbifem's agenda and was not the motivation of their taking up the streets. LB+ feminists' queer looks and their "advanced" approach to queer and trans politics surprised Western lesbians who presumed that the lack of certain legal rights in a given context would result in "less developed" political perspectives and the avoidance of being out in the public space. As non-Western activists, Yonca and her friends felt homogenized by their Western counterparts who, from a superior position, evaluated what kind of political practice was to be celebrated without knowing much about the Turkish context and the diversity within feminist and queer communities; they found this attitude objectifying and patronizing.

Yonca's reflections on the 1 st $\mathrm{EL}^{*} \mathrm{C}$ in Vienna can be considered in line with Wiedlack's critique of visibility politics which, in solidarity practices across the East-West divide, maintains "notions of Western superiority and Eastern backwardness" (2019, 26). Western LGBTI+ solidarity prioritizes visibility and public participation as "high point of modernity and progress" (Ibid.); when non-Western activists adopt different agendas than visibility and social and legal change, they might not be recognized by Western actors and fall outside of the scope of transnational solidarities. At the same time, Yonca applied a similar type of homogenization onto the organizers and what she saw as White, Western participants of the conference by referring to the two groups as "they" throughout the interview without acknowledging the diversity within these groups. Among the organizers as well as participants there were many from the Balkans, Eastern Europe, and Central Asia $\left(E L^{*} \mathrm{C}\right.$ n.d.) who might have shared a similar disadvantaged position vis-à-vis their West European counterparts despite their whiteness and taken-for-granted identification as Western. Yonca's awareness about class differences between activists in her own context vanished when it came to others'; she safely assumed that conference organizers could afford the type of accommodation they arranged for incoming presenters. Taking pride in the way her $\mathrm{LB}+$ feminist community bridged feminist and queer struggles and handled trans inclusivity, Yonca also reinstated the 
East-West divide but this time by elevating the non-Western context to a superior position.

\section{Challenging Regional and Geopolitical Belongings}

To counterbalance the critique toward Western activists as a homogeneous group of people and disappointment with their class and racial blindness provided in Yonca's narrative, we give the example of another conference which coincidentally also took place in Vienna, at the University of Vienna premises, in September 2017. The conference was titled "Fucking Solidarity: Queering Concepts on/from a Post-Soviet Perspective" and, according to the program, raised the questions "What kind of solidarities is needed and is useful to our friends and comrades within the post-Soviet space and/or postcolonial context? And how does what we, the White privileged western academics and activists as well as migrants and refugees coming from post-Soviet and other spheres do now and did in the past, to meet these needs?" (Fucking Solidarity n.d., 3). The conference was organized by a group of Austria-based queer activists and academics with or without a background in the post-Soviet space. According to Kathi Wiedlack, a queer activist and scholar from Austria who co-organized the conference, they "wanted to use resources connected to academia to develop concepts and approaches to create meaningful solidarity between Western and post-Soviet queer scholars, activists, and artists and at the same time challenge hegemonies" (Wiedlack 2019, 34). Hence, the conference raised questions that we as scholars asked ourselves and our research partners within our research for this book, namely how solidarity can be established in unequal power relations, and how complicities and hegemonies can be challenged. The conference gathered together a remarkably diverse body of activists, scholars, and artists from various regions including the former Soviet Union, Western and Northern Europe, and Turkey. Olga attended the conference without a presentation using it as an opportunity to get to know activists and scholars with whom we could collaborate within the Spaces of resistance project. In exchange, Olga offered her help as a session moderator and as a synchronous translator. 
During four days Olga visited an impressive variety of activities from activists' presentations of their work to artistic performances and exhibitions. Speaking all conference major languages (Russian, English, and a bit of German) and experiencing many struggles addressed during the conference (being an academic migrant from the post-Soviet Belarus in Western academia), Olga felt comfortable and sympathized with many critical interventions that took place. However, she felt uneasy at times when Western/Northern academics and activists were addressed too straightforwardly and were explicitly required to be held accountable for their privileges.

We unpack the roots of this uneasy feeling in dialogue with Kathi Wiedlack's (2019) autoethnographic conceptualization of queer solidarity where she draws on her experience of co-organizing the conference. The first reason for such feelings of discomfort is related to the space/format of the conference which was more academic than activist. As mentioned, the conference took place in the university building and it was academic in format - it consisted of panels and moderated sessions some of which were also purely academic in their content. As Wiedlack writes about this when she reflects on her experience of "solidarity failures" during the conference:

Our first mistake was that, although we had intended to appropriate the academic setting to support activists and artists, as well as non-academic forms of knowledge productions, we rather incorporated the latter into the exclusionary format of an academic conference... (Wiedlack 2019, 39)

The "exclusionary format of an academic conference" refers here to a standardized academic setting of a scholarly conference with a strict time regulation, an expected format for paper presentations and Q\&A sessions. This format, however, turned out problematic for inclusion of other modes of presenting knowledge such as film screenings or artistic performances. As Wiedlack reflects further, certain artistic expressions remained underrepresented as a result of this dominant academic logicuniversity classrooms occurred unsuitable to artistic performances and strict time limits frustrated those artists and activists who were not used 
to the "accelerated timelines of the neoliberal university" (Mountz et al. $2015,1238)$. In agreement with this vision, we want to add one more dimension of academic experiences where the clash between activism and academia is salient, namely an affective regime of academia that, unlike art or activism, remains suspicious to emotions and any other ways of personalized engagement in the production and presentation of knowledge (e.g., Widdowfield 2000). Explicit rage, frustration, or admiration are still rare emotional registers of formal academic gatherings including conferences where emotional expressions are in the best case reserved for informal interactions. Yet, these are precisely the feelings that Hemmings considers as most important for "a sustainable feminist politics of transformation" $(2012,148)$. This is, in our view, where the unexpected uncomfortableness of encountering other ways of facing difficult issues, which in the case of "Fucking Solidarity" often emerged from artistic and activist circles during formal panels and roundtables, comes from. Having socialized predominantly within academic spaces during the past seven years, Olga found the emotionally charged register of conference interactions unexpected and at times threatening. Exactly as Wiedlack says, the fact that the conference took place in academic premises and was mainly academic in format was adding to the dissonance in Olga's perception of this event and interactions that happened there in the formal space of the conference panels. Our interpretation is also in line with the intentions of conference organizers who wrote in their address to academics from the North/West that the conference was "not a space that was created for you, so you can feel cozy and safe and curious about us (post-Soviet queers and migrants) and our contexts. We will challenge you here and there, as you challenge us every day, throughout our migrant every day realities" (Fucking Solidarity n.d., 5).

The quote above where Western and Northern academics are interpellated as entitled to "coziness and safety" of intellectual exchange ("curiosity") is important for understanding the second reason of Olga's uneasiness and uncomfortableness during the conference. Being herself a post-Soviet migrant with commitment to feminist and queer struggles in the region of her origin, why was she feeling challenged and "uncozy" an emotion that was assigned to Western/Northern academics? This feeling was strong during some exchanges, in particular, when one of 
the presenters was bluntly asked "to check his Western privilege and gaze by a non-Western queer and female identified person" (Wiedlack 2019, 35). Olga found this interpellation very uncomfortable and unsafe while Kathi Wiedlack experienced the feelings of guilt and shame for failing to create a solidarity space where non-Western participants would not be provoked to the extent that they felt the need to approach a speaker in such a blunt manner (Ibid., 40). Wiedlack writes about this incident as illuminating the complex dynamics in solidarity spaces where "White privileged Westerners" feel hurt when their well-intended gestures of solidarity and support are left unanswered or are explicitly challenged by those for whom solidarity is meant. In her "working through" the feelings that rise in such interactions, Wiedlack reveals the heterogeneity of "Western" activists and/or academics in their ethical commitments and a position they occupy participating in solidarity actions.

In the spirit of Wiedlack's suggestion to "work through feelings" in order to deconstruct privileges (Wiedlack 2019, 40), we maintain that the sense of discomfort that some encounters raised were related to Olga's own complicity in unfair and hierarchical academic structures of the West. When "Western" subjects were approached with particular negativity, Olga could not entirely distance herself from this interpellating experience. She had an early-career position at a Swedish university. She came to the conference in Vienna because she had funding from a research project supported by a private foundation in Sweden. Therefore, she could afford to stay in a hotel while some other participants including those with presentations had to stay in shared apartments and commute to the conference venue long distance. Moreover, the conference was a part of Olga's professional activities. In line with the dominant idea of activist politics as driven by "passion"” (Roy 2011), a professional commitment felt slightly as a betrayal of the solidarity ideal.

Read together, the accounts of Kathi, Olga, and Yonca underline how the categories of "West" and "East" fluctuate and change their meaning in solidarity practices through attention to affective and material dimensions of transnational solidarity spaces. The examples of two conferences we unfolded here show how feelings destabilize one's identity or other

3 For Roy's (2011) critique of contrasting "passion" and "profession" in activism, see Chapter 3. 
group characteristics such as "Western activist," "Turkish queer," or "feminist post-Soviet migrant in Western academia," which, according to Hemmings (2012), is what transformative feminist politics currently need. Encounters between LB+ feminists from Turkey and whom they considered as Western feminists, or between post-Soviet queer migrants and "Western" scholars, or even among "Western" scholars and activists, provide space for getting to know each other, learning about each other's realities for individuals or groups who are asymmetrically positioned members of an imagined coalition. They result in the destabilization of established perceptions of the Other, oftentimes through disappointment and disillusionment alongside the sheer enjoyment of the physical gathering of a loosely defined global community. Yet, the above examples also expose the need for further communication between activists about the East-West and activism-academia divides and thinking together around issues that are now conceived as omnipresent in activist spaces regardless of geographical location. All in all, close attention to affects involved in encounters across divides shows that a success vs. failure approach is too simplistic to understand the dynamics of transnational solidarity practices. The discovery and recognition of "unbridgeable gaps" (Hemmings 2012) between differently positioned parties can be seen as part of a process through which feminist and queer struggles transform. The coming together of activists does not operate outside of and cannot transcend global inequalities (Ahmed 2014, 163). Thus, as Wiedlack argues, failures are necessary elements of solidarity attempts as they reflect "not only (...) personal shortcomings but also (...) structural problems" (Wiedlack 2019, 22). Approaching dissonances between activists from this perspective is valuable as it allows for an understanding of negative affects such as anger, disappointment, and feeling of exoticization as part of transnational solidarities in a way that reconstructs the idea of solidarity across difference as a possibility rather than an obligation. 


\section{Hymn Singing and Anti-Colonial Resistance: Solidarity as Shared Labor}

In contradistinction to understandings of solidarity that emphasize homogeneity, we are influenced by scholars who have developed further Durkheim's (1968) theorization of organic solidarity (Wiedlack 2019). Rather than searching for a position of resemblance or common identity, these scholars bring forth understandings of solidarity as shared labor across difference and highlight the usefulness of conceptualizing solidarity as doing or acting in everyday life (Wiedlack 2019; Augustin and Jørgensen 2016). In the following, we attend to the collaborative work involved in solidarity as such everyday doing or acting.

While in feminism, solidarity and interdependence has been variously defined as either global sisterhood or solidarity across difference (Rai 2018), in socialist traditions, solidarity has been translated to rational expressions arising from class reflexivity (Fish 2002; Mansueto 1988). Durkheim (1995 [1912]) approached solidarity as a moral value, as a weave that kept societies together. He recognized the significant role of religion for nourishing popular struggles against relations of oppression and proposed that religion may bind individuals together into a social being greater than themselves (Mansueto 1988; Redekop 1967). In difference from places and relations of mechanical solidarity-characterized by resemblance and homogeneity - in which empathy or charity was the basis of morality, Durkheim argued that in contexts of organic solidarity_characterized by diversification and individuality-justice was the basis of moral action (Schoenfeld and Meštrović 1989; Giddens 1986). ${ }^{4}$ Our approach is influenced by theorizations that have developed Durkheim's ideas around organic solidarity to conceptualize solidarity as a form of working together (Wiedlack 2019). Such an act of working together includes confrontation of dominance and deconstruction of hierarchies between the parties involved (Wiedlack et al. 2019). Shared labor does not rely on empathy but takes a critical or transformative

\footnotetext{
${ }^{4}$ Moving beyond the limitations of charity and empathy which relies on, and functions to sustain, particularistic relationships between the members of the social system, the idea of justice as the basis of modern or organic solidarity allowed Durkheim to seek solutions to social problems within the larger social system itself (Schoenfeld and Meštrović 1989).
} 
approach to injustices, challenging material inequalities, and focusing on redistribution as the outcome of solidarity practices (Wiedlack 2019). Approaching solidarity as a working together allows us to recognize both material and emotional dimensions of solidarity work, which otherwise might become overshadowed (Binnie and Klesse 2012). This is a form of solidarity that acknowledges that all involved have something to gain from the collective act and does so by setting in motion structural effects which go beyond the personal.

In what follows, we examine practices of religiosity among the Sami people in Kirkenes in northern Norway and reveal how religiosity can express acts of solidarity in which memory, belonging, and culture are renegotiated and reclaimed through religious rituals. Below, we focus on the experience of hymn singing as embodied and affective shared labor, approaching this performance as a collective work of solidarity that confronts the violent acts of state actors and institutions, historically and presently (Mahmood 2016; Pine et al. 2000). In focus is not just the act of singing or emotions connected to the performance, but the deeper historical and broader everyday context surrounding it. We approach this phenomenon as an example of shared labor in a mundane setting, capable of building political and social change from the ground up through a long-term struggle involving people of different belongings in the region, as well as institutions such as the church and the church council, all of which had important roles making the hymn singing possible. The analysis is introduced with an ethnographic vignette.

\section{Practices of Faith as Solidarity Work}

It is a chill and sunny September day. I have already spotted the white church on the hill. Together with Olga, I am visiting the small town of Kirkenes to participate in Barents Pride, a collaborative Pride event organized by Russian and Norwegian LGBTI+ activists to express solidarity across borders. As we round the corner of the church building and take the few steps up to the entrance door, I see a pride flag tied to the rail, waving in the light wind (see Fig. 4.1). We are warmly greeted by Noor and Ane, two of the organizers of Barents Pride and as we enter 
the church, I receive a leaflet presenting the liturgy and the hymns of the Rainbow mass we are about to attend. Olga and I take a seat next to each other in one of the benches. About three quarters of the benches are already full. When I later speak with Magnus, the cleric, he says that there were more people visiting this mass than usual, also many visitors whom he was surprised to see there. The ceremony is performed in Norwegian, Russian and Sami languages. An Orthodox priest holds a speech in Russian and a Sami woman reads a text and gives a short speech in Sami. As we sing the hymns in the three languages, I am overwhelmed by a feeling of belonging to the diverse collective in the church and I remember the broken connection to my Sami heritage on my mother's side. In my later conversation with Magnus, he says that he found the Rainbow mass an important event for the local inhabitants, not least in relation to Sami perspectives: "You should know that in this place, the process of Norwegianization (fornorskning) was strong. Up until the 1970s-80s, the authorities had an explicit goal that people belonging to Sami and Kven ${ }^{5}$ communities should become Norwegian. During the acculturation period, the authorities inflicted feelings of shame among these populations for not being good enough and pressing them to become something else than what they were. The same goes for non-heterosexual people, who carry similar feelings of not being good enough." Magnus finds it important that the church took such an outspoken and firm position during the Barents Pride. He tells me that one of the families he was surprised to see in the Rainbow mass later said to him that they have a grandchild who identify as LGBTI+. They found liberating that the institution which has expressed the strongest prejudices now opens up to accept people as they are.

The weeks following Barents Pride, Mia kept on thinking about the presence of Sami and LGBTI+ perspectives in the Rainbow mass. She became more intensely aware of the feelings of shame among the older generations which have erased the connections to the Sami heritage

\footnotetext{
5The Kven people are a Balto-Finnic ethnic minority in Norway. From the late nineteenth century until the late twentieth century, the name Kven was a derogatory term. Among some members of the community it is still regarded as such, while others have reclaimed it, along with the revitalization of Kven culture from the 1980s onwards. Since 1996, the Kven people have had minority status in Norway and since 2005, their language is recognized as a minority language in Norway.
} 


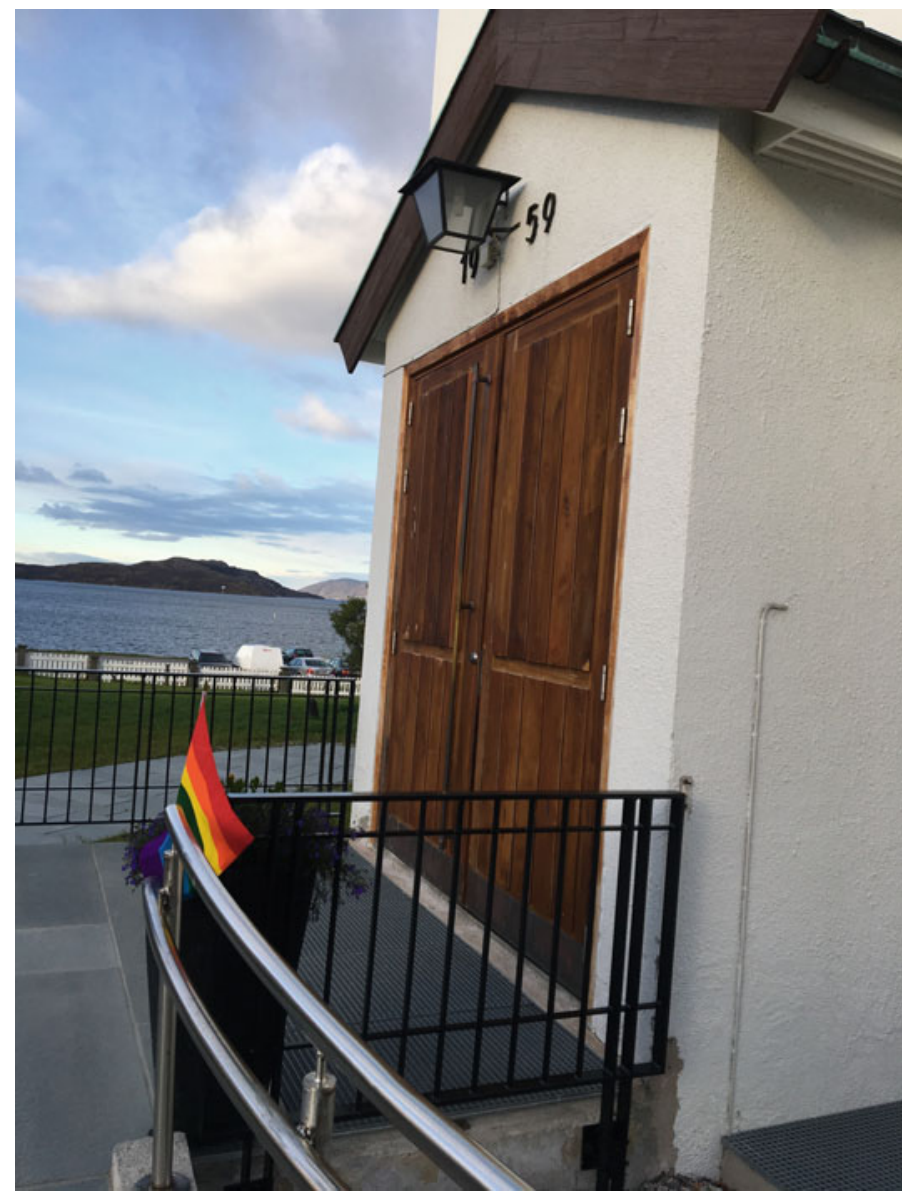

Fig. 4.1 Pride flag waving in the light wind outside of Kirkenes Church (Photo Credit: Mia Liinason)

in her own family. She contacted Máijá, the Sami woman who had performed during the mass, to learn more about the function of the church and religion in the Sami anti-colonial struggle in Kirkenes.

"Since 1993," Máijá explained, she had been engaged on "a voluntary basis with Sami church services, with a special focus on women and children." She recalled this as the year when the secretary general 
of the Sami Church Council recruited volunteers and Máijá was encouraged to travel to Geneva to attend a network meeting against racism for minority women in Europe. Once back home, Máijá assembled a group of interested women in the area and asked them what they wanted to do to revitalize the Sami community. "One can be interested in doing many things [to reconnect to Sami culture]," Máijá told me, "such as knitting or speaking Sami, but this group of women, they only wanted to sing." Basing her work on the principle of self-determination, Máijá followed the suggestion of the group. "So we sang, the hymns we had been listening to and singing at home as children." As the Norwegianization process had banned everything Sami-the language, traditions, and culture-these women hadn't heard these hymns for fifty or sixty years.

Mia also contacted Magnus, the cleric from the Rainbow mass. He told her that the struggle for Sami rights and community revival in the region is almost exclusively conducted by women: "20 years ago," Magnus said, "no one here said they were Sami. The Norwegian assimilation process had been strong. Now this has changed. For the Sami revitalization process to take place, the church played an important part." He referred to the hymn singing project started up by Máijá, and recalled from the church services during these years that people were crying in the church benches: "For those people, who haven't heard their own language since they were children, neither spoken, nor sung, the experience of singing hymns in one's own language gave strong reactions."

As an affective and embodied practice, women's hymn singing expresses an anti-colonial resistance against the violent assimilationist process of the Norwegian nation-state. Within this performance, the recollection of histories hidden reveals a legacy of struggle for selfdetermination and agency that stretches across centuries (Hämäläinen et al. 2018; Protopapas and Kaur 2011). In Norway, a harsh assimilation process toward the Sami community was executed through the educational system and other public institutions. The period of assimilation took its starting point in the early nineteenth century and continued until the mid-1980s, being at its most intense between 1851 and 1959. This was a period during which the idea of Norwegianization was proclaimed based on the notions of the racial superiority of ethnic 
Norwegians and on nation-building ambitions to create a homogenous nation-state with a unified population identified with a particular place and territory. These ambitions were especially strong in the period following World War II (Bjørklund 1985; Eriksen and Niemi 1981). A large number of Sami children were placed in boarding schools far away from their homes with the purpose to assimilate them to the dominating culture. In the schools, the use of Sami language was banned and children had to learn and speak in Norwegian (Hætta 2002; Bjørklund 1985; Pedersen and Høgmo 2012; Minde 1998). As of today, the majority of Sami is integrated as part of the Norwegian society. Simultaneously, the revitalization of culture, language, and community in Sápmi has grown strong and conscious efforts are made to preserve the Sami culture. In 1989, the Sami Parliament of Norway was founded and Sami was recognized as a third official language alongside the two existing official forms of Norwegian: Bokmål (book tongue) and Nynorsk (New Norwegian) (Hämäläinen et al. 2018). ${ }^{6}$ In the region of Kirkenes, the boundaries between ethnic belongings have blurred and the identity as Norwegian, according to Magnus, weakened:

My own family is almost not Norwegian at all. They are Sami, Kven, Finns... They were attacked at school if they spoke Sami, they were beaten if they spoke to each other in Finnish. Since the church started to recognize the Sami heritage - and especially when we keep worships in the countryside-for elderly Sami people, it is a strong experience to sing hymns in Sami language. They cry because they haven't heard this for so

\footnotetext{
${ }^{6}$ Until 2017, the Norwegian church was part of the state, after which it finally became independent. Historically, the church has been one of the actors who have carried out the worst abuses toward the Sami people. In 1826, when the Norwegian territorial borders were redrawn, Kirkenes became a part of Norway. For the Sami people in the area, the new border forced them to choose whether they would belong to Russia or to Norway, resulting in enforced migrations and a social catastrophe among the community, according to Magnus. To realize the nation-building ambitions, the church became a key institution in this area and churches were built to mark Norwegian sovereignty in relation to Finland and Russia. In the years that followed, clerics in the Norwegian church abused their power to keep the Sami people obedient and submissive, among other things by selling cheap booze and taking reindeer herds as pawns. During the same time, the progressive Laestadian movement began to spread in the area. Sami women were inspired by its liberatory message, emphasizing Sami self-determination and taking a distance from the Norwegian state. Still today, the Laestadian movement is influential among the Sami population although it has become a more dogmatic and conservative movement.
} 
long, these are hymns they know, which they have forgotten. The mother tongue sits deep.

In these narratives, the ritual and collective shared experience of hymn singing takes shape as a kind of healing or repair. As several studies have shown, there is a connection between singing "as a means of self-expression, regulation of emotions, and health and well-being" (Hämäläinen et al. 2018, 4; Moss et al. 2018). Yet, these performances are not only personally rewarding but also give effects that go beyond the personal. By reiterating counter-memories, such memories that fall outside of the concept of a unified, homogenous nation, alternative routes to recognition and shared identity are forged and, in this case, transmitted through the shared collective practices of hymn singing (Richardson 2000; Pine et al. 2000). Rather than searching for cultural or social unity, the multiple belongings and positions of the people involved, belonging to diverse ethnicities and religions and with different positions in society, illuminate this performance as an act of shared labor, as a practicing of solidarity in which "two or more parties (...) collaborate towards a collective goal” (Wiedlack 2019, 24).

\section{Material and Symbolic Redistribution Through Shared Labor}

While expressions of affect and collective performance are important instances for recognizing and confronting social hierarchies and exclusions, scholars have acknowledged the difficulties of generating "structural transformation through projects of collective feeling" (Pedwell and Whitehead 2012, 121; Berlant 2006). Nonetheless, rather than remaining located in an affective register or limited to awaken feelings of empathy among the Norwegian population, the anti-colonial project of singing Sami hymns incited a process of broader transformation in the region. As inequalities were taken seriously through the collective work of solidarity as shared labor, a process of material and symbolic redistribution was generated. In this, several actors were involved: institutions such as the Norwegian church, which later took the responsibility for 
the Sami church services, and the Sami Church Council that encouraged Máijá to travel to the UN in Geneva and attend the anti-racist network meeting for minority women. Individual actors were also central, not least Máijá and the group of elderly women who took up the practice of Sami hymn singing in the first place, as well as the cleric Magnus who learned Sami language and have continued to fight for the practice of Sami church services to become accepted among all clerics in the parish and the broader region. A broader group of inhabitants in Kirkenes also took part in these ceremonies and in the singing itself. Afterward, they stayed true to the moment shared, which built a sense of community across different belongings and positionalities. The importance of the two social movements in the region, the labor movement and the Laestadian movement, were also mentioned by Mia's research partners who saw these shaping an important foundation for the Sami revitalization process as well as for the more recent, ongoing struggle to recognize LGBTI+ people's rights. According to Magnus, these movements have brought a spirit of life and a sense of community among inhabitants in the region without which people wouldn't have continued to live there, and through which other injustices could be recognized, challenged, and transformed. In contrast to welfare state solidarity (solidarity through paying tax) which was strongly articulated in Norway, as in all the Scandinavian countries, during the twentieth century and arguably functioned to sustain the assimilationist project of Norwegianization through its exclusionary emphasis on national homogeneity, the Sami revitalization process in Kirkenes demonstrates how relations of solidarity can flow in multiple directions to include participants of different belongings and positionalities and incite changes that go beyond the participants themselves.

Such building of complex webs of "mutuality and reciprocity over time" (Kelliher 2018, 5; Brown and Yaffe 2017) distinguishes solidarity from charity, and has the potential to stimulate changes in broader political discourses and societal structures. These changes didn't happen overnight but were the result of a slow and lengthy process, stretching across thirty years. This process is far from over but, according to Magnus and Máijá, the activity of keeping church services in Sami has not only revitalized the Sami community in the church but also had an effect on 
the whole municipality: "When I moved from the municipality in 1998 to study at the university in Oslo," Magnus says, "people were saying that, "No, this municipality is not Sami. There are no Sami living here. Those who wear the Sami colt here come from Kautokeino. But here, there are none."”

"After six years," he continues, "I return, and there have been great changes, because people have begun to talk with their grandparents, 'Where do you come from? What is the history of this place?' And if you attend May 17 [the day of the Norwegian constitution], you see a lot of people wearing the Sami colt in the parade. But the colt was a dress you should burn, you shouldn't keep it. It belonged to the old. It doesn't take much to abolish a whole population." Magnus explained that such genocide was about to happen, as the Sami people were almost "done away with." But now, he said, this has changed. "If before," he remarked, "people were using Sami or Finnish when they didn't want their small children to understand, today, they use English."

Máijá explained that they started with the activity of singing Sami hymns during church services in 1996 and continued until 2006. By that time most of the women involved had become too old and now most of them are passed away. They set as their goal to make the institution of the church responsible for keeping up the work with Sami presence. Today, there are four Sami masses per year in the area, with Sami language, hymns, and content in the worship, and the cleric uses Sami language. However, it is not only the language which is affected by Sami inclusion in the church, but Sami self-determination impacts on the preparation of the church service and the theology is influenced by Sami cosmology. In similarity with several other indigenous systems of belief, the Sami cosmology is based on the idea of nature as having subjectivity. The relationship with nature resembles a close relationship to another human being. In this view, nature is not an object but has an independent existence which humans should be respectful of (Leinebø Ekre 2018). Máijá describes that it has been immensely difficult for them to make Norwegian clerics understand Sami cosmology. However, since five years back, the Norwegian church council is taking a more active role in relation to this and expects all members of congregations in the north 
to include Sami in the masses and learn about Sami theology/cosmology. Although the responsibility for including Sami presence in the masses now lies with the church, Magnus clarifies that the participation and involvement of Sami people in the church service is very important: "They [people belonging to the Sami community] have ownership and decide what hymns we are going to sing and we talk about the sermon, the text for the sermon, and about how this relates to our congregation at large."

Yet, despite the fact that many things have changed for the better as people belonging to the Sami community have a greater visibility and real influence in the municipality, significant challenges remain. Máijá explains that Sami children are still bullied at school and that Sami reindeer herders are involved in tough fights against the forces of capital, as state actors want to force them to move because of economic interests to expand the oil extraction in the area which is rich in natural resources. These struggles also take place within the Sami community itself, and tensions emerge between people of Sami background who are more and less assimilated into the Norwegian society. Máijá explains that it is heavy but that people belonging to the Sami community in the area who have not assimilated survive because they are part of an active transnational Sami network stretching across Norway, Sweden, and Finland. In the context of these ongoing struggles, and considering the support of her transnational network, Máijá found it "such a positive feeling to stand in the church and read a text in Sami on the Rainbow mass during Barents Pride."

\section{The Role of Religion in Justice Struggles}

In the evening of the day of the Rainbow mass, a panel conversation was organized by the Barents Pride. The panel was composed of a Norwegian cleric; a priest from the Orthodox Church of Ukraine; an organizer of the Pride from the Russian side; and one Pride organizer from the Norwegian side. The moderator asked Elena, the Russian panel participant, why it is important to address religiosity and faith at a Pride festival. Elena responded that: 
LGBTI+ people are the same kind of people as anyone else but religious LGBTI+ people have to live with a deep religious trauma. To search for strength in faith has historically been important for people. If you are excluded from your family, from your circle of friends and from society, it is difficult not only because they exclude you as an LGBTI+ person but also as a human being, and as this happens, you are not able to seek support in church. It is a heavy burden to carry, not being recognized as a human being in your community.

Later, Elena explained: "I believe in human beings. I don't have much belief in states. But direct contact is always the most fruitful and I always look for people who have the ability to stay human. People who are capable of feeling emotions and acting in human ways." By connecting the human-worldliness with faith and the sacred, Elena destabilizes the division between secularity and religion and shows the importance of both in bridging differences and overcoming injustices (van den Brandt 2014). In this perspective, rather than directing attention away from the world, religiosity can offer support for queers of faith to conduct themselves more strenuously in the world, and religiously inflected feelings can build a frame for a reflective form of reason (van Doorn 2015; Taylor et al. 2014).

Today, the shared collective experience of hymn singing in the church in Kirkenes has resulted in significant changes in the municipality, carrying a process of material and symbolic redistribution that is still ongoing. While it began as a small-scale project among Sami women, the collective performance of religious ritual and hymn singing has not only inspired cross-generational exchanges in the area and a sense of pride in Sami language and heritage but also an interest in recollecting and sharing histories hidden in the municipality. Taken together, the Rainbow mass, the Sami revitalization process, and the reflections of Máijá, Magnus, and Elena show the crucial role that religion and religiosity can play in solidarity struggles across different belongings and positionings. They illuminate the emotional potential of religion as a capacity to bind individuals together and create a spirit of community, enabling a space for organic solidarities and intersectional justice struggles to develop. 


\section{Ambivalences of Transnational Campaigns}

As we discussed in Chapter 3, broader political and socioeconomic changes of the past decades created similar conditions for feminist and queer struggles across the global North-South and West-East, but also perpetuated global inequalities, and therefore had diverse results in different contexts. Transnational solidarity campaigns became more powerful, wider in scope in terms of both participation and agendas and, thanks to the advancement in digital technologies, more inclusive of communities that are marginalized in their local contexts. Increased number of INGO local branches in different parts of the world have also facilitated the coordination of solidarity action. In recent years, campaigns and mobilizations such as \#MeToo, Ni Una Menos, the International Women's Strike, and Las Tesis posed powerful responses to developments that result in the deterioration of the living conditions of women and LGBTI+ people. Many other campaigns took place on regional, national, and sub-national levels with the aim of alleviating injustices. Transnational solidarity campaigns and their local adaptations created novel possibilities of mutuality and linkage within and between feminist and queer struggles. Yet, as we show through two examples in this section, transnational solidarity campaigns are not always smoothly adapted or do not necessarily lead to positive outcomes in local contexts. Instead, they might be detrimental for local struggles as they produce or crystallize tensions between activists within and across borders. In the case of transnational campaigns around local issues, local events can be instrumentalized to further the cause of ally groups and organizations elsewhere. Similar to transnational solidarity practices across geopolitical, epistemological, and professional divides we have discussed in the first section, solidarity campaigns produce ambiguous results where consensus and conflict, and harmony and dissonance go together, and different affects are produced in different instances and on multiple scales. 


\section{Local Implications of Global Campaigns and Disputes Over Feminism}

One line of inquiry in the Turkish case study was to understand how activists affiliated with the Women Are Strong Together initiative (Kadınlar Birlikte Güçlü, hereafter Strong Together) situated their work vis-à-vis the recent wave of global feminist mobilization. As described in Chapter 1, transnational exchange of logos, slogans, as well as analytical approaches and political programs became a significant source of inspiration for Strong Together activists. An event organized by Strong Together and its aftermath revealed how transnational campaigns, the International Women's Strike in this case, could foster solidarities while bringing to surface disagreements over feminism within the group. Largely a coalition between feminist, left-socialist, and (pro-)Kurdish women, Strong Together was formed in Istanbul but, as the slogan "Women Are Strong Together" gained nation-wide popularity, already existing women's platforms with similar composition in various cities in Turkey have considered the possibility of re-naming themselves as Strong Together and thereby making the Istanbul-based initiative into a national one. Motivated by this possibility and the need to synchronize women's struggles across the country, Strong Together activists organized the Turkey Women's Gathering in Istanbul on 5-6 January, 2019. Nearly a thousand women participated in this meeting, which became a historic event in terms of the variety of women's and LGBTI+ groups it brought together, representing nearly forty cities—i.e., every second city-from all around Turkey.

The two-day gathering started with an opening session with small presentations by women's platforms from various cities ${ }^{7}$ where participants briefly talked about their motivation for attending the event as well as the most significant women's issues in their locales. As event organizers, Strong Together activists in Istanbul emphasized two things in

${ }^{7}$ Convenors of the Gathering were women's platforms in the cities of Adana, Ankara, Antakya, Batman, Bursa, Diyarbakır (Amed), Hatay, Istanbul, Izmir, Kocaeli, Mardin, Mersin, Samsun, Urfa, and Van. 
particular. First, that Strong Together in Istanbul went beyond the longstanding divisions between formal and informal women's groups as well as between those women who identified as feminist and those who did not. Strong Together activists were not mere representatives of their respective organizations; over time they had become friends and, in return, friendship gave their politics enormous strength. "Our differences are not a weakness or disadvantage but a great source of power," they said. The second point of emphasis was the rising mobilization of women on a global level, which was in line with the view of solidarity across difference Strong Together promoted: "Solidarity gives strength to our movement and, with this, we know we can move the world. We know this from women's uprisings in Argentina and Iran, from Iceland to the US, and Poland to Spain, where women [went for a strike] for freedom, bodily autonomy, labor [rights] and [recognition of their] identities. (...) and now here, as the women's movement in Turkey, we feel similarly powerful!" This was followed by a video clip of footage from the International Women's Strike action in several countries. Activists from other cities' platforms also expressed in their presentations their desire to organize a women's strike in Turkey to draw attention to the burning issues of gender-based violence, poverty, war, and environmental destruction. At the end of the opening session, participants were enthusiastic to move on to discussing, in smaller groups, the common issues and points of strength of the women's movement as well as its weaknesses and failures. The second day of the Gathering was organized in plenary sessions where participants shared insights from the previous day's group discussions and debated on the possibility of jointly pursuing future agendas. During these plenaries too, organizing across differences and transnational solidarities, particularly the one around the International Women's Strike, came out as two significant points that inspired women from different locales and political belongings — although not unanimously, as we see below.

Two months after this gathering, Selin met Rengin in Ankara for an interview. Rengin was organized in Woman Defense Network (Kadın Savunma $A \breve{g l}$ ), a recent (2017) independent socialist feminist initiative by women affiliates of Folk Centers (Halkevleri). She represented her 
organization at the Ankara Women's Platform and was one of the organizers of the Platform's participation in the Turkey Women's Gathering. At the time of the interview, Rengin strongly identified with Strong Together's agenda to synchronize different women's struggles in Turkey. She saw feminism as a linkage between local and global struggles for gender equality and sexual rights, and found the Gathering a powerful moment for enhancing the feminist movement in Turkey. When asked what kind of inspiration she drew from transnational campaigns, Rengin said:

They (...) show that we are not alone in Turkey[;] (...) women all over the world have common problems. Some people might think, say, 'Women in more democratic countries live under favorable conditions.' That's not true; it's a lie and [these campaigns] very well reveal this lie. Women in Argentina, Poland, even in the US and Ireland have, like those in Turkey, problems with governments that attempt at their right to decide on their bodies-like [the right to] abortion. (...) [W] hen I see those feminist crowds in Argentina, I think like, 'This can also happen in Turkey, in Ankara; why not to organize it?' I think this is such a positive influence.

Rengin then moved on to talking about how transnational campaigns were similar to what she observed at the Gathering. The reason why the Gathering was so exciting for her was because it refuted the prejudice that feminism was a Western import and only a certain-privileged-group of women could relate to it. "For example, we had women coming from Erzincan; from Adana, Trabzon, Artvin, Bodrum, where else; Mersin and Şırnak-really from all corners of Turkey!” Here, what Rengin referred to as West was not only the global North. From a multi-scalar point or view, she addressed the global North and the western, more developed part of Turkey simultaneously. Just like transnational campaigns revealed the salience of feminism across the global North and South, so had the Gathering made clear that feminism did not appeal only to women in Turkey's developed, urban areas. Prior to the Gathering, feminists in those smaller cities were not aware of each other's struggles. This turned the Gathering into a moment of collective realization of the salience of feminist struggles everywhere; on national, sub-national, and global scales. The correlation Rengin drew between the Gathering 
and transnational campaigns challenged arguments that associated feminism with Western imperialism and bourgeois ideology (Basu 1995). As feminist struggles proliferated and became more visible in countries and locales across the East-West and North-South divides, it transformed the status of feminism in the eyes of those who perceived it as irrelevant to their local struggles.

As reflected in Rengin's words, solidarity campaigns encourage activists to understand their local struggle from a transnational lens as opposed to essentialist interpretations of politics of location where gender-based oppression is linked to under-development, Islam, or the war-laden Middle East political geography. Witnessing the rise of right-wing populism and anti-gender mobilizations in the "democratic" West and seeing that the recent opposition to the concept of gender and the Istanbul Convention in Turkey draws heavily on discourses on women's and LGBTI+ rights produced in countries such as Hungary, Poland, and Austria, activists become more likely to understand contextual differences between "East" and "West" in terms of varieties of neoliberalism, conservatism, and religious fundamentalism. This challenges and subverts asymmetric understandings of solidarity where activists in countries that are considered as more advanced in gender equality and sexual rights support others who struggle with their misogynist and homophobic governments and/or cultures. Feminism, however, continues to be a topic of contention in the Turkish context. At the Gathering, it became obvious that some women saw feminism as a threat-now even more so in the context of transnational solidarities. During the closing session, a thick feeling of tension replaced those of enthusiasm and togetherness in the opening session when conflict broke over whether to add "feminist solidarity" in the final declaration of the Gathering as a source of mobilization for women in Turkey. Several participants one after another opposed the mentioning of feminism in the final declaration, claiming that it was not a common denominator for women; it was not invariably what brought women together to this Gathering. These participants criticized the Strong Together group for formulating their composition as one of women who identified as feminist and those who did not. Such a formulation, they argued, undermined the differences between women who did not identify as feminist and thereby 
treated feminists as favored constituents of the women's movement. In response to these criticisms, other participants defended feminism and expressed their frustration about "allergic reactions" to feminism. Among those who identified as feminists, there were different views. According to some, it was indispensable to name feminists as proper subjects of the women's movement; not mentioning feminism would make feminists invisible as political subjects; feminism (understood as a women-only form of organizing) was what mobilized women in mix-gender leftwing organizations into gender equality struggle; it was heartbreaking that some women viewed it as an imposition. Other feminists saw no point in insisting on feminism as a common denominator and thought it was fair to not mention it in the final declaration. Yet others said they were both socialist and feminist and saw no necessary conflict between these belongings. It was clear that participants would not reach any consensus on this issue. When the Gathering ended, many participants had a dispirited expression on their faces, and organizers were in despair.

Following the Gathering, the divide over feminism marked the ensuing discussion on the International Women's Strike. Later in January 2019, Strong Together held a meeting in Istanbul in order to evaluate the Gathering and to decide on how to proceed with the idea of a women's strike that was embraced by many participants. Those who opposed the mentioning of feminism in the final declaration were also against a women's strike in Turkey because, they thought, the working class was politically weak and could not afford a strike at the time being. Most of these women belonged to the Labor Party (Emek Partisi, hereafter EMEP) a Marxist-Leninist organization which, unlike many other leftsocialist organizations such as Rengin's, did not have an autonomous women's section. EMEP women were against women's separate organizing but they took part in women's platforms in various cities as representatives of their party. In relation to the International Women's Strike, their view was that feminists were appropriating an important working-class tool for a cause that would have no positive impact on the material conditions of working women. Prior to Strong Together's evaluation meeting, EMEP women published in their media outlet their own evaluation of the Gathering. The evaluation targeted precisely the idea of solidarity across difference and claimed that this idea was in 
practice a "majoritarian imposition": "The women's movement have always accommodated different views, organizations, and institutions. (...) Discussions around the final declaration of the Gathering, however, showed that this progressive aspect of the women's movement has now weakened. (...) the reality is that we were (...) accused of 'hostility' when we expressed our differences. (...) Women Are Strong Together, as it sets out with 'feminist rebellion' to organize a 'feminist strike,' does not accommodate our views" (Ekmek ve Gül 2019). With this criticism, EMEP women withdrew first from discussions around the International Women's Strike, and later altogether from Strong Together in Istanbul. In women's platforms in several other cities, their resistance to the International Women's Strike and Strong Together's efforts to synchronize local agendas resulted in a loss of enthusiasm around linking together local agendas and organizing a nation-wide mass women's strike.

Unlike the two conferences in Vienna we discussed in the first section, in the case of Strong Together the "unbridgeable gaps" in solidarity practices had to do with irreconcilable visions of addressing gender equality and sexual rights rather than structural inequalities. The Women's Gathering and its aftermath became an experience that "limit[ed] crosscutting ties in favor of a 'primary' loyalty" instead of building on the intersections of gender and labor "to foster coalitions" (Ferree and Roth 1998, 644). EMEP women's resistance to embracing feminism as a motivating force in a coalition they participated in created "a difficult tension for those aiming to enact intersectional solidarity" (Einwohner et al. 2019, 18). Yet, the conflict over feminism and the International Women's Strike cannot be said to have caused permanent damage to Strong Together constituents' general adherence to community- and coalition-building. This is because, first, EMEP women continued collaborating with those groups they disagreed with during the Gathering on the occasion of other transnational solidarities, such as in defending the Istanbul Convention, showing the "temporary, specific, and strategic" (Ferree and Roth 1998, 643) nature of solidarity practices. Second, following their withdrawal from Strong Together, EMEP women invested more energy in politicizing the issues of women workers, started publishing an online newsletter on their activities, and launched a YouTube channel to reach 
out to wider audiences. ${ }^{8}$ Considering that women workers' problems were not necessarily high on Strong Together's agenda as this coalition mainly defended policies and legal frameworks on gender equality, but not raised demands for improving the material condition of specific groups of women, EMEP women's decision to go solo can be seen under a different light. As Einwohner et al. argue (2019), separate organizing of groups that experience marginalization in a given coalition, "rather than reflecting a weakening of the movement, may represent an evolution of movement thinking about particular issues or groups" (17).

\section{Complicity and Responsibility in Cross-Border Solidarity}

Another example of complex relations between transnational, national, and local scales in solidarity practices comes from Russia. We unpack the ambivalent effects of transnational solidarity with LGBTI+ people from the Chechen Republic. In Spring 2017, Russian national and international media outlets exploded with outrageous news about stateinitiated homophobic persecutions of LGBTI+ people in Chechnya (Brock and Edenborg 2020). The news caused a wave of solidarity actions on multiple levels involving LGBTI+ activists in Russia and all over the world, transnational human rights organizations, and international political bodies such as the EU and Council of Europe (Brock and Edenborg 2020; Smirnova 2019). The Russian LGBT Network, the largest LGBTI+ non-governmental organization with representation across the whole of Russia, acted promptly and helped rescuing queer people from Chechnya. It relied on extensive international support both financially through funds allocated by transnational organizations and politically through convincing foreign governments to provide asylum to rescued people (Smirnova 2019). In the interview with Irina, a Russian activist from "Perspective," a Moscow-based community center for LGBTI+ people (see Chapter 3), who was actively engaged in the work on rescuing people from Chechnya, she gives an example of

${ }^{8}$ Ekmek ve Gül on Youtube: https://www.youtube.com/channel/UCK-yNZP1hUVgv-EUX JqmOWQ; see also https://ekmekvegul.net/. 
tremendous support and solidarity from the Swedish civil society. She recalls this example in the context of our broader discussion of Perspective's collaboration with partners abroad. Among the usual suspects such as foreign embassies in Russia or large INGOs, she mentions more "unexpected encounters" that positively impress her understanding of transnational solidarity. In particular, she talks about a Swedish LGBTI+ foundation who announced a donation campaign in Sweden to tackle homophobic persecutions in Chechnya. The money was aimed at very specific expenses - to provide financial help to LGBTI+ people from Chechnya who were asking for asylum in Sweden. Irina was impressed by the promptness and genuineness of the response:

You may think where Chechnya is and where Sweden is. Nonetheless... I saw that it was not simply a political decision when some political figure decides to allocate support, these were sympathizing people. You may think, what is their concern? Why would they care about our Caucasus? This is very strange for me. It would not cross my mind to empathize with some, I don't know, the Japanese. Probably, with a particular person, yes, but to imagine that the whole country collects money to help our (...) poor (...) This was very surprising for me. The mentality is probably different. Perhaps we will grow to be like them. The Swedes.

Irina considers this type of solidarity as an ideal that other people, including Russians, have to aspire to. She finds it positively surprising that people in another country show so much care about the situation of LGBTI+ people in Russia. She also consciously distinguishes this sort of genuine, people-to-people, solidarity from more politically motivated solidarity actions initiated by particular political figures who may use transnational solidarity for promoting their own political agenda. Olga who interviewed Irina tries to provoke this line of thinking, questioning a somewhat essentialist idea of the philanthropic mentality of Swedes as opposed to careless Russian people. She asks whether the reason for such generosity can be related to the resourcefulness of the Swedes ("Probably, they just have more resources to help?"). Irina does not want to change her mind. She says in reply, "Yes, I was surprised how momentarily they mobilized. Wonderful people!”. 
In contrast to Irina's account we turn to the interview with Elena who, back in 2017, worked in the head office of a prominent international human rights organization which we call Human Rights International (HRI) here. Elena, herself originally from the post-Soviet region and a Russian speaker, has been long working in international human rights organizations which covered the LGBTI+ agenda in the post-Soviet space. When the news about Chechnya reached HRI, the organization responded with substantial financial and technical support helping in rescuing operations. However, in the longer run, the symbolic cost of this support did not satisfy Elena. The first bell rang when she was asked by the European office of the organization "to find a Chechen who could come to the Pride [in one of the West European cities].” Elena recalled: "I got furious! You know, I just wanted to shout at them. People are escaping from the situation when their lives are at stake, and there is a Chechen diaspora in Europe. What Chechen on the Pride? Are you out of your mind?" Elena meant that bringing a queer person from Chechnya to a Pride in Europe could expose a person to the danger of being outed by the Chechen diaspora in Europe. Then she also started noticing that the organization exploited the Chechnya case in campaigns to raise money, which, however, were not directly aimed at supporting people in danger or LGBTI+ community in general but rather on accumulating resources for the organization. Elena felt that the usage of the Chechnya case was close to a widespread fundraising strategy, when the pictures and images of atrocious human rights violations all over the world are demonstrated to rich philanthropists who are asked to show their solidarity by supporting the organization financially. She admits that she understands this strategy when the resources are then indeed spent on those victims of violations. However, she felt that this was not always the case for HRI. The organization used regions like Chechnya or the Middle East for short-term marketing campaigns because violations there attracted a lot of media attention and they were easy to wrap into a convincing message about the importance of HRI's work. At the same time, HRI often failed to allocate money or other resources for laborious long-term advocacy work in these regions which could have prevented such atrocities in the first place. 
Elena's account raises several issues that are discussed in the literature on transnational solidarities as well as in activist circles. The first is related to the ambivalences of the visibility paradigm in LGBTI+ politics (Edenborg 2017; Stella 2015; Richardson 2017). Many transnational solidarity efforts evolve around creating "visibility for Russian LGBTIQ+ people and feminists, often in efforts to make their national governments exercise pressure on Russia" (Wiedlack 2019, 26; see also Neufeld and Wiedlack 2019). Apparently, as Elena's story shows, HRI relied on the same strategy when they wanted to bring a queer person from Chechnya to a Pride demonstration in Europe. Yet, this strategy does not take into account that for some people visibility increases vulnerability. In the case of Chechnya, as mentioned above, the danger that visibility could expose people to and make them an easy target of the Chechen diaspora in Europe was not even considered, when the idea was put on Elena's table. Importantly, we heard a similar critique from Russian activists in relation to some Russian-based LGBTI+ activists and organizations which exposed people for advocacy purposes at the expense of their safety. Also, while at a regional level queer existence in the Chechen Republic was made invisible by the President of the Republic Ramzan Kadyrov who denied the existence of LGBTI+ people in Chechnya (Brock and Edenborg 2020, 3-4), it underwent hypervisibilization in national and international media outlets and solidarity actions. The "spectacular dimension" (Brock and Edenborg 2020, 4) of the persecutions draw attention to the homophobic traditions and history of the Caucasus region and Russia in general. This is in line with how some liberal politicians from the Russian opposition and mainstream Russian feminists use women's oppression in the Caucasus for the construction of racist anti-Chechen sentiments in the public discourse in Russia (Reznikova 2014). As Wiedlack argues, the consequence of this "perpetual re-narration of Chechen (as well as Russian) tradition and history as anti-LGBTIQ+" fortifies "the state-sanctioned erasure of queer histories and lives from these cultures and traditions altogether, focusing exclusively on damage and pain rather than on resistance and resilience" (2019, 42). 
The focus on damage and pain, or victimhood, ${ }^{9}$ is another theme that is strikingly present in Elena's narrative. In her interview, she starts talking about Chechnya in the broader context of discussing a fundraising strategy of "squirting out tears" from resourceful organizations and people. She describes how organizations where she worked organize fundraising dinners where they demonstrate documentaries of White people saving children in the Central African Republic (CAR). When we discuss how she feels when a similar strategy is applied to the post-Soviet region where she comes from, she says:

Elena: It feels strange when it applies to us. When I worked with propaganda ["gay propaganda" law in Russia], which pictures are selected for press-releases... How miserable LGBT people in Russia are. This discourse annoys me because it concerns me personally and very directly. When it comes to a child in CAR, I think, because of my privileges, this works on me, this exoticization of African children.

Olga: But do you agree that these two representations have something in common?

Elena: They are the same!

What Elena refers here to is a representational regime that produces "politics of pity" (Brock and Edenborg 2020, 17) and raises empathy among distant observers who voyeuristically watch the documentaries about "the rescue of African children" or suffering of queer people in Russia while simultaneously eating an expensive dinner on the boat sailing along Amsterdam's canals, as Elena describes. The critique of such solidarity practices considers "transnational politics of empathy" (Pedwell 2012) as "being embedded in colonial politics and the logic of global economy" (Wiedlack 2019, 38). Politics of empathy and pity contributes to self-transformation of more privileged subjects without necessarily a deeper understanding of their complicity with and responsibility for global inequalities, resulting in violence and exposure of vulnerable groups of people (Pedwell 2012). Empathy may develop into a paternalistic attitude toward the victims of violence who are considered as lacking agency and subjectivity (Wiedlack 2019). In fact, such an

\footnotetext{
${ }^{9}$ A similar example of activists' resistance to reproduction of victimhood in fundraising campaigns in the national context of Norway is discussed in Chapter 3.
} 
attitude was at first demonstrated by some Western-based activists who assisted asylum seekers from Chechnya (Smirnova 2019, 145). This may possibly constrain solidarity actions perpetuating Western privilege and "the Western model of gay activism" (Brock and Edenborg 2020, 15).

While we wholeheartedly align with the intention to problematize politics of empathy and pity in transnational solidarity practices, we also want to highlight that this critique has to be nuanced in order to avoid being dismissive of any solidarity action with the involvement of actors who are unequally positioned in global hierarchies. We consciously provide two different views on transnational solidarity with Chechnya LGBTI+ people because they shed light on different aspects of transnational solidarity practices and variegated perceptions of solidarity efforts by different actors. Even though Swedish people who donated money for the support of unknown and distant "Chechnya gays" may have been driven by the misleading idea of shared identity or empathy and pity with less fortunate people from a cruel backward region, as Chechnya is sometimes imagined even within Russia (Reznikova 2014), we see from Irina's account that for her and other activists who invested efforts to rescue people these donations had a crucial symbolic and material meaning. Although these donations are part of the global moral economy of unevenly distributed privileges, they are directed to people in need and they do help rescue at least several lives literally. Elena's critique does not undermine this positive dimension of transnational solidarity by any means. But it does highlight a somewhat darker side of good intentions. Exploitative circulation of cruel images of distantly suffering people contributes to maintaining hierarchies between tolerant, democratic, and well-meaning Western saviors and non-Western victims of savage, cruel cultures, and political regimes (Mutua 2001). The cost of such solidarity practices is that the myriad of creative ways to live, love, care, and resist in such circumstances remain unacknowledged.

\section{Conclusion}

In this chapter we discussed solidarity practices ranging from informal, community-oriented activism to globalized political coalitions with a 
focus on their symbolic and material dynamics and embodied, affective dimensions. Based on an understanding of solidarity as politically motivated efforts of community- and coalition-building taking place on multiple scales and in multiple life fields, we argued for the indispensability of transnational solidarities for the making of feminist and queer spaces of resistance. Drawing inspiration from an emerging body of literature (Ahmed 2014; Butler 2018; Chowdhury and Philipose 2016; Connections 2020; Hemmings 2012; Salem 2017; Pedwell 2012; Wiedlack et al. 2019), we challenged the duality of consensus and conflict, success and failure, and harmony and dissonance in approaching solidarity practices, and argued instead for understanding negative affects as constitutive of sustained collaboration between diverse struggles for gender equality and sexual rights. Providing ethnographic accounts of small-scale, everyday, mundane acts of solidarity; attempts to organize across the East-West and North-South divides; and participation in solidarity campaigns on local to global levels, we built on this emerging literature by integrating a transnational perspective to the discussion. We further developed the notion of solidarity across difference (Dean 1996; Mohanty 2003) by exploring different kinds of difference such as those pertaining to racial/ethnic, religious, professional, political and geopolitical belongings, processes and relations within and across national borders. Our findings highlight ambivalences inscribed in solidarity projects and suggest that solidarity "cannot be presumed - it must be fought for and made real through individual and collective action. It requires tough conversations" (Emejulu 2018).

By way of concluding we would like to foreground the ways in which feminist scholarship can advance such an understanding. First, solidarity research would benefit from engaging more in discussions on the ambivalences of community- and coalition-building practices and critically interrogating and confronting power dynamics embedded in solidarity projects as opposed to simply acknowledging material inequalities between parties. As our discussion of the 1st European Lesbian* Conference (2017, Vienna) and the Fucking Solidarity Conference (2017, Vienna) showed, important here is to systematically dehomogenize categories of analysis, such as for instance, West-East and North-South, when studying transnational solidarities through sustained awareness 
in research of the multilayeredness of belonging in a complex, globalized world. It is due to this multilayeredness that collaboration and conflict, pleasure and pain go together in solidarity practices; actors' assumptions around shared identities are always-already disrupted by various structural inequalities that destabilize these assumptions. Individuals or groups that aim to build bridges across borders, belongings, and movements, regardless of their well-meaning intentions, can-and often do-end up with undesirable and unfavorable outcomes and negative affects. In this regard, another aspect of the ambiguity inscribed in transnational solidarities that is worth exploring is the tension between individuals' and organizations' desire to support and transnationalize local struggles elsewhere and their own complicities and responsibilities in the reproduction of global inequalities. As we saw in the case of the campaign against the homophobic persecutions of LGBTI+ people in Chechnya, well-intentioned politics of empathy might result in failed solidarity by exposing to violence the vulnerable groups who are on the receiving end of transnational campaigns. Yet, as we elaborate in the chapter, failure in solidarity practices can be productive in that it highlights existing tensions previously unacknowledged by the actors involved, bringing forth new initiatives and different ways of affective, symbolic, and material engagements.

Second, grasping solidarity practices as forms of shared labor (Wiedlack 2019) enables deeper comprehension of how material inequalities can preclude as well as be addressed in feminist and queer struggles by calling attention to the practical and emotional work activists engage in on an everyday basis to build solidarities. We believe that the perspective of shared labor has a capacity to bring a stronger emphasis in solidarity research on the significance of redistribution of symbolic and material resources in building political and social change from the ground up. The collaboration between Máijá, Magnus, and many others in their anti-colonial struggle in the Norwegian town of Kirkenes, an account of which we offered in this chapter, is a good example of the transformative potential of long-term embodied and affective shared labor.

Third, and relatedly, research would benefit from more focus on longevity as a crucial aspect of solidarity practices that are a part of broader struggles for social justice. Only through time and persistent 
commitment participants of solidarity projects become legible to each other and develop a culture of working together. Singular or short-term engagements or initiatives where different parties do not have a possibility for cultivating face-to-face, affective relationships might bear more risk of damage and failure when confronted with conflict and dissonance. Coalition groups on various scales are always in the making with conflict and tension as much their engine as affinity and consensus resulting in temporary-or permanent-withdrawal of their constituents, as seen in the disagreements between some feminist and socialist women in Turkey around the International Women's Strike events. At the same time, there is no teleological relationship between moments of damage and failure and the long-term outcomes of solidarity efforts; negative affects and experiences in one moment, especially if collectively acknowledged and worked through, might lead to more resilient communities and coalitions in the long run. Genealogical investigations that tackle the interplay between momentary and overall appearances of solidarity practices and the co-construction of and dis/continuity between different spaces of solidarity are thus invaluable for developing conceptualizations of solidarity across difference beyond nation-bound and rights-oriented frameworks.

\section{References}

Ahmed, Sara. 2014. The Cultural Politics of Emotion. 2nd edition. New York: Routledge.

Antrobus, Peggy. 2004. The Global Women's Movement: Origins, Issues and Strategies. London and New York: Zed Books.

Augustin, Óscar García, and Martin Bak Jørgensen. 2016. Solidarity Without Borders: Gramscian Perspectives on Migration and Civil Society. London: Pluto Press.

Baksh, Rawwida, and Wendy Harcourt, eds. 2015. The Oxford Handbook of Transnational Feminist Movements. New York: Oxford University Press.

Bassel, Leah, and Akwugo Emejulu. 2017. Minority Women and Austerity: Survival and Resistance in France and Britain. Bristol and Chicago: Policy Press. 
Basu, Amrita, ed. 1995. The Challenge of Local Feminisms: Women's Movements in Global Perspective. Boulder: Routledge.

Benería, Lourdes, Günseli Berik, and Maria S. Floro. 2015. Gender, Development and Globalization: Economics as if All People Mattered. 2 edition. New York and London: Routledge.

Berger, Stefan, and Sean Scalmer, eds. 2018. The Transnational ActivistTransformations and Comparisons from the Anglo-World Since the Nineteenth Century. New York: Palgrave Macmillan.

Berlant, Lauren. 2006. "Cruel Optimism.” Differences 17 (3): 20-36.

Binnie, Jon, and Christian Klesse. 2012. "Solidarities and Tensions: Feminism and Transnational LGBTQ Politics in Poland." European Journal of Women's Studies 19 (4): 444-59.

Birey, Tegiye, Celine Cantat, Ewa Mączyńska, and Eda Sevinin. 2019. Challenging the Political Across Borders: Migrants' and Solidarity Struggles. Budapest: Central European University Press.

Bjørklund, Ivar. 1985. Fjordfolket i Kvanangen: Fra Samisk Samfunn Til Norsk Utkant 1550-1980. Tromsø: Universitetsforlaget.

Brandt, Nella van den. 2014. "Secular Feminisms and Attitudes Towards Religion in the Context of a West-European Society-Flanders, Belgium." Women's Studies International Forum, no. 44: 35-45.

Brock, Maria, and Emil Edenborg. 2020. "'You Cannot Oppress Those Who Do Not Exist': Gay Persecution in Chechnya and the Politics of In/Visibility." GLQ: A Journal of Lesbian and Gay Studies 26 (4): 673-700. Brown, Gavin, and Helen Yaffe. 2017. Youth Activism and Solidarity: The NonStop Picket Against Apartheid. London: Routledge.

Butler, Judith. 2018. "Solidarity/Susceptibility." Social Text 36 (4/137): 1-20. Chowdhury, Elora, and Liz Philipose, eds. 2016. Dissident Friendships: Feminism, Imperialism, and Transnational Solidarity. Urbana, Chicago and Springfield: University of Illinois Press.

Connections. 2020. "Disappointed Hopes: Reclaiming the Promise of Resistance." Workshop Organized by University of Edinburgh, Centre for Ethics and Critical Thought, 07.12.2020-09.12.2020. Connections: A Journal for Historians and Area Specialists.

Dean, Jodi. 1996. Solidarity of Strangers: Feminism After Identity Politics. Berkeley: University of California Press.

Doorn, Niels van. 2015. "Forces of Faith: Endurance, Flourishing, and the Queer Religious Subject.” GLQ 21 (4): 635-66. 
Dufour, Pascale, Dominique Masson, and Dominique Caouette, eds. 2010. Solidarities Beyond Borders: Transnationalizing Women's Movements. Vancouver: University of British Columbia Press.

Durkheim, Émile. 1968. The Division of Labor in Society. New York: Free Press. 1995. The Elementary Forms of Religious Life. New York: Free Press.

Edenborg, Emil. 2017. Politics of Visibility and Belonging: From Russia's "Homosexual Propaganda" Laws to the Ukraine War. London and New York: Routledge.

Einwohner, Rachel L., Kaitlin Kelly-Thompson, Valeria Sinclair-Chapman, Fernando Tormos-Aponte, S. Laurel Weldon, Jared M. Wright, and Charles Wu. 2021. "Active Solidarity: Intersectional Solidarity in Action." Social Politics: International Studies in Gender, State \& Society 28 (3): 704-29.

Ekmek ve Gül. 2019. "Türkiye Kadın Buluşmasının ardından...” Ekmek ve Gül, January 26, 2019. https://ekmekvegul.net/gundem/turkiye-kadin-bul usmasinin-ardindan.

EL*C. n.d. "Why A EuroCentralAsian Lesbian* Community?" https://europe anlesbianconference.org/about-elc/.

Emejulu, Akwugo. 2018. "On the Problems and Possibilities of Feminist Solidarity: The Women's March One Year On.” IPPR Progressive Review 24 (4): 267-73.

Eriksen, Knut Einar, and Einar Niemi. 1981. Den Finske Fare: Sikkerhetsproblemer Og Minoritetspolitikk i Nord 1860-1940. Oslo: Universitetsforlaget.

Fernandes, Leela. 2013. Transnational Feminism in the United States: Knowledge, Ethics, and Power: Knowledge, Ethics, Power. New York: NYU Press.

Ferree, Myra Marx, and Silke Roth. 1998. "Gender, Class, and the Interaction Between Social Movements: A Strike of West Berlin Day Care Workers." Gender and Society 12 (6): 626-48.

Fish, Jonathan S. 2002. "Religion and the Changing Intensity of Emotional Solidarities in Durkheim's The Division of Labour in Society (1893)." Journal of Classical Sociology 2 (2): 203-23.

Fucking Solidarity. n.d. "Book of Abstracts 'Fucking Solidarity: Queering Concepts on/from a Post-Soviet Perspective'.” September 20, 2017. https:// qp8.univie.ac.at/fileadmin/user_upload/p_qp8/Book_of_Abstracts_EN.pdf.

Gender \& Development. 2013. "Special Issue: Feminist Solidarity and Collective Action." Gender \& Development 21 (2): 217-379.

Ghodsee, Kristen. 2019. Second World, Second Sex: Socialist Women's Activism and Global Solidarity During the Cold War. Durham: Duke University Press. Giddens, Anthony. 1986. Durkheim, Politics and the State. Stanford: Stanford University Press. 
Grewal, Inderpal. 2005. Transnational America: Feminisms, Diasporas, Neoliberalisms. Durham: Duke University Press.

Haan, Francisca de. 2018. "The Global Left-Feminist 1960s: From Copenhagen to Moscow and New York." In The Routledge Handbook of the Global Sixties: Between Protest and Nation-Building, edited by Chen Jian, Martin Klimke, Masha Kirasirova, Mary Nolan, Marilyn Young, and Joanna Waley-Cohen, 230-42. London and New York: Routledge.

Hætta, Odd Mathis. 2002. Samene: Nordkalottens Urfolk. Kristiansand: Høyskoleforlaget.

Hämäläinen, Soile, Frauke Musial, Anita Salamonsen, Ola Graff, and Torjer A. Olsen. 2018. "Sami Yoik, Sami History, Sami Health: A Narrative Review." 77 (1): 1-8.

Hemmings, Clare. 2012. "Affective Solidarity: Feminist Reflexivity and Political Transformation." Feminist Theory 13 (2): 147-61.

Irvine, Jill A., Sabine Lang, and Celeste Montoya, eds. 2019. Gendered Mobilizations and Intersectional Challenges: Contemporary Social Movements in Europe and North America. Illustrated edition. London and New York: ECPR Press.

Jain, Devaki. 2005. Women, Development, and the UN: A Sixty-Year Quest for Equality and Justice. Bloomington: Indiana University Press.

Jong, Sara de. 2017. Complicit Sisters: Gender and Women's Issues Across NorthSouth Divides. New York: Oxford University Press.

Keck, Margaret E., and Kathryn Sikkink. 1998. Activists Beyond Borders: Advocacy Networks in International Politics. Ithaca: Cornell University Press. Kelliher, Diarmaid. 2018. "Historicising Geographies of Solidarity." Geography Compass, no. 12: 1-12.

Kulpa, Robert. 2014. "Western Leveraged Pedagogy of Central and Eastern Europe: Discourses of Homophobia, Tolerance, and Nationhood." Gender, Place \& Culture 21 (4): 431-48.

Leinebø, Ekre Eldbjørg. 2018. Jordvenn-Venn Med Hele Skaperverket: Trosopplaring i Praksis. Oslo: IKO Forlaget.

Lezbifem. n.d. "lezbifeministler.com-." lezbifeministler.com. http://lezbifeminis tler.com/.

Mahmood, Saba. 2005. Politics of Piety. Durham: Duke University Press. - 2016. Religious Difference in a Secular Age: A Minority Report. Princeton: Princeton University Press.

Maiguashca, Bice. 2016. "Transnational Feminism: Still a Useful Concept?" In Handbook of Gender in World Politics, edited by Jill Steans and Daniela Tepe-Belfrage. Oxford: Edward Elgar. 
Mansueto, Anthony. 1988. "Religion, Solidarity and Class Struggle: Marx, Durkheim and Gramsci on the Religion Question." Social Compass 35 (2-3): 261-77.

Martinsson, Lena, and Diana Mulinari, eds. 2018. Dreaming Global Change, Doing Local Feminisms Visions of Feminism: Global North/Global South Encounters, Conversations and Disagreements. New York and London: Routledge.

Meyer, Mary K., and Elisabeth Prügl, eds. 1999. Gender Politics in Global Governance. Lanham, Boulder, New York and Oxford: Rowman \& Littlefield Publishers.

Minde, Henry. 1998. "Constructing 'Laestadianism': A Case for Sami Survival?” Acta Borealia 15 (1): 5-25.

Mohanty, Chandra Talpade. 2003. Feminism Without Borders: Decolonizing Theory, Practicing Solidarity. Durham and London: Duke University Press.

—. 1984. "Under Western Eyes: Feminist Scholarship and Colonial Discourses." Boundary 2 12/13 (3/1): 333-58.

Moss, Hilary, Julie Lynch, and Jessica O'donoghue. 2018. "Exploring Perceived Health Benefits in Singing in a Choir: An International Cross-Sectional Mixed-Methods Study." Perspectives in Public Health 138 (3): 160-68.

Mountz, Alison, Anne Bonds, Becky Mansfield, Jenna Loyd, Jennifer Hyndman, Margaret Walton-Roberts, Ranu Basu, et al. 2015. "For Slow Scholarship: A Feminist Politics of Resistance Through Collective Action in the Neoliberal University." ACME: An International Journal for Critical Geographies 14 (4): 1235-59.

Mutua, Makau W. 2001. "Savages, Victims, and Saviors: The Metaphor of Human Rights." Harvard International Law Journal 42 (1): 201-45.

Neufeld, Masha, and Katharina Wiedlack. 2019. "Visibility, Violence, and Vulnerability: Lesbians Stuck between the Post-Soviet Closet and the Western Media Space." In LGBTQ+ Activism in Central and Eastern Europe: Resistance, Representation and Identity, edited by Radzhana Buyantueva and Maryna Shevtsova, 51-76. Cham: Palgrave Macmillan.

Pedersen, Paul, and Høgmo Asle. 2012. Sápmi Slàr Tilbake: Samiske Revitaliserings- Og Moderniseringsprosser i Siste Generasjon, edited by Solbakk Trygve John. Kárášjohka: Č́lliidLágádus.

Pedwell, Carolyn. 2012. "Affective (Self-) Transformations: Empathy, Neoliberalism and International Development." Feminist Theory 13 (2): 163-79.

Pedwell, Carolyn, and Anne Whitehead. 2012. "Affecting Feminism: Questions of Feeling in Feminist Theory." Feminist Theory 13 (2): 115-29. 
Pine, Frances, Deema Kaneff, and Idis Haukaness, eds. 2000. Memory, Politics and Religion: The Pasts Meets the Presents in Europe. Berlin: Lit Verlag. Popa, Raluca Maria. 2009. "Translating Equality Between Women and Men Across Cold War Divides: Women Activists from Hungary and Romania and the Creation of International Women's Year." In Gender Politics and Everyday Life in State Socialist Eastern and Central Europe, edited by Shana Penn and Jill Massino, 59-74. New York: Palgrave Macmillan.

Protopapas, Janice, and Gurleen Kaur. 2011. "Kirtanchaunki: Affect, Embodiment and Memory." Sikh Formations 7 (3): 339-64.

Puar, Jasbir K. 2007. Terrorist Assemblages: Homonationalism in Queer Times. Illustrated edition. Durham: Duke University Press.

Rai, Shirin M. 2018. "The Good Life and the Bad: Dialectics of Solidarity." Social Politics: International Studies in Gender, State \& Society 25 (1): 1-19.

Redekop, Calvin. 1967. "Toward an Understanding of Religion and Social Solidarity.” Sociological Analysis 28 (3): 149-61.

Reznikova, Olia. 2014. "Rol' kategorii gender i race $\mathrm{v}$ issledovanii postcolonial'nosti v Rossii. Oplakivaemost' i chechenskii feminism." In $\mathrm{Na}$ pereput'e: Metodologiia, teoriia i praktika LGBT i kvir-issledovanii, edited by Aleksandr Kondakov, 24-41. Tsentr nezavisimykh sotsiologicheskikh issledovanii. https://cisr.pro/publications/na-pereputye-book/.

Richardson, Julia. 2017. "Not Seen and Not Heard: The Security Dilemma of in/Visibility." Critical Studies on Security 5 (1): 117-20.

Richardson, Tanya. 2000. "Disciplining the Past in Post-Soviet Ukraine: Memory and History in Schools and Families." In Memory, Politics and Religion: The Pasts Meets the Presents in Europe, edited by Pine, Frances, Deema Kaneff, and Haldis Hauknes, 109-29. Berlin: Lit Verlag.

Roy, Srila. 2011. "Politics, Passion and Professionalization in Contemporary Indian Feminism.” Sociology 45 (4): 587-602.

- 2016. "Women's Movements in the Global South: Towards a Scalar Analysis." International Journal of Politics, Culture, and Society 29 (3): 289306.

Salem, Sara. 2017. "On Transnational Feminist Solidarity: The Case of Angela Davis in Egypt." Signs: Journal of Women in Culture and Society 43 (2): 245-67.

Schoenfeld, Eugen, and Stjepan G. Meštrović. 1989. "Durkheim’s Concept of Justice and Its Relationship to Social Solidarity." Sociological Analysis 50 (2): 111-27.

Scholz, Sally J. 2008. Political Solidarity. University Park: Penn State University Press. 
Scholz, Sally. 2014. "Transnational Feminist Solidarity and Lessons from the 2011 Protests in Tahrir Square." Global Discourse, no. 4: 205-19.

Smirnova, Elena. 2019. "Could You Show Me Chechnya on the Map? The Struggle for Solidarity Within the Support Campaign for Homosexual Refugees from the North Caucasus in France." In Queer-Feminist Solidarity and the East/West Divide, edited by Katharina Wiedlack, Saltanat Shoshanova, and Masha Godovannaya, 231-61. Oxford and New York: Peter Lang.

Social Politics. 2018. "Special Section: The Good Life and the Bad: A Discussion.” Social Politics: International Studies in Gender, State \& Society 25 (1): $1-49$.

Spivak, Gayatri Chakravorty. 1996. “'Woman' as Theatre.” Radical Philosophy, no. 75 (February): 2-4.

Stella, Francesca. 2015. Lesbian Lives in Soviet and Post-Soviet Russia: Post/Socialism and Gendered Sexualities. Basingstoke: Palgrave Macmillan.

Taylor, Yvette, Emily Falconer, and Emily Snowdon. 2014. "Queer Youth, Facebook and Faith: Facebook Methodologies and Online Identities." New Media \& Society 16 (7): 1138-53.

Weldon, S. Laurel. 2018. "Some Complexities of Solidarity: A Commentary on Shirin Rai's 'The Good Life and the Bad: Dialectics of Solidarity'." Social Politics: International Studies in Gender, State \& Society 25 (1): 34-43.

Widdowfield, Rebekah. 2000. "The Place of Emotions in Academic Research." Area 32 (2): 199-208.

Wiedlack, Katharina. 2019. "Fucking Solidarity." In Queer-Feminist Solidarity and the East/West Divide, edited by Wiedlack, Katharina, Saltanat Shoshanova, and Masha Godovannaya, 21-50. Oxford and New York: Peter Lang.

Wiedlack, Katharina, Saltanat Shoshanova, and Masha Godovannaya, eds. 2019. Queer-Feminist Solidarity and the East/West Divide. Oxford and New York: Peter Lang.

Winslow, Anne, ed. 1995. Women, Politics, and the United Nations. New York: Praeger. 
Open Access This chapter is licensed under the terms of the Creative Commons Attribution 4.0 International License (http://creativecommons.org/ licenses/by/4.0/), which permits use, sharing, adaptation, distribution and reproduction in any medium or format, as long as you give appropriate credit to the original author(s) and the source, provide a link to the Creative Commons license and indicate if changes were made.

The images or other third party material in this chapter are included in the chapter's Creative Commons license, unless indicated otherwise in a credit line to the material. If material is not included in the chapter's Creative Commons license and your intended use is not permitted by statutory regulation or exceeds the permitted use, you will need to obtain permission directly from the copyright holder.

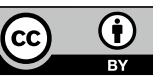

